\title{
Acute lymphoblastic leukemia presenting with bilateral serous macular detachment
}

\section{Leucemia linfoblástica aguda com descolamento macular seroso bilateral}

\author{
Luisa Vieira ${ }^{1}$, Nuno Aguiar Silva ${ }^{1}$, Marco Dutra Medeiros ${ }^{1,2}$, Rita Flores ${ }^{1,2}$, Vitor Maduro ${ }^{1,2}$
}

\begin{abstract}
Acute lymphoblastic leukemia is a malignant hematopoietic neoplasia, which is rare in adults. Although ocular fundus alterations may be commonly observed in the course of the disease, such alterations are rarely the presenting signs of the disease. Here we describe the case of a patient with painless and progressive loss of visual acuity (right eye, 2/10; left eye, 3/10) developing over two weeks, accompanied by fever and cervical lymphadenopathy. Fundus examination showed bilateral macular serous detachment, which was confirmed by optical coherence tomography. Fluorescein angiography revealed hyperfluorescent pinpoints in the posterior poles. The limits of the macular detachment were revealed in the late phase of the angiogram. The results of blood count analysis triggered a thorough, systematic patient examination. The diagnosis of acute lymphoblastic leukemia B (CD10+) was established, and intensive systemic chemotherapy was immediately initiated. One year after the diagnosis, the patient remains in complete remission without any ophthalmologic alterations.
\end{abstract}

Keywords: Acute lymphoblastic leukemia; Serous macular detachment; Visual acuity; Optical coherence tomography; Fluorescein angiography

\section{RESUMO}

A leucemia linfoblástica aguda é uma neoplasia maligna das células hematopoiéticas, incomum em adultos. Apesar da maioria dos casos apresentar alterações no fundo ocular no decurso da doença, estas são raramente forma de apresentação da mesma. Descreve-se o caso de uma doente com diminuição progressiva e indolor da acuidade visual (OD 2/10 e OE 3/10), que apresentava concomitantemente febre e adenopatias cervicais, com duas semanas de evolução. À oftalmoscopia apresentava descolamento seroso macular bilateral, confirmado por tomografia de coerência ótica. A angiografia fluoresceínica revelou pequenas lesões hiperfluorescentes tipo pinpoints no polo posterior. Nos tempos médios e tardios do exame adivinham-se os limites da bolsa do descolamento do neuroepitélio. As alterações encontradas no hemograma suscitaram um estudo sistêmico extenso. O diagnóstico de leucemia linfoblástica aguda B (CD10+) foi efetuado, iniciando-se, de imediato, quimioterapia sistêmica intensiva. Um ano após o diagnóstico a doente continua em remissão e sem alterações oftalmológicas de novo.

Descritores: Leucemia linfoblástica aguda; Descolamento seroso macular; Acuidade visual; Tomografia de coerência ótica; Angiografia fluoresceínica

\section{INTRODUCTION}

Acute lymphoblastic leukemia (ALL) is a malignant hematopoietic neoplasia, which is rare in adults ${ }^{(1,2)}$. In this condition, lymphoid precursors proliferate and replace normal marrow elements. Lymphoblasts also proliferate in other organs, most commonly in the liver, spleen, and lymph nodes ${ }^{(1)}$. Patients with ALL frequently present with fever and other symptoms related to either the lack of normal marrow cells (anemia, neutropenia, and thrombocytopenia) or symptoms related to the direct infiltration of the marrow or other organs by leukemic cells ${ }^{(1)}$. In contrast to pediatric ALL, and despite intensive treatment, only $20 \%-46 \%$ of adults with ALL are cured ${ }^{(1,3)}$.

Almost any ocular structure can be affected by leukemia, either through direct infiltration, hemorrhage, or ischemia (due to anemia, thrombocytopenia, or leukostasis) oras a consequence of opportunistic infections ${ }^{(4)}$. The fundus of patients with ALL often exhibit intraretinal and/or white-centered hemorrhage, tortuous dilated veins, cotton wool spots, vascular sheathing, and leukemic infiltrates ${ }^{(4,5)}$; meanwhile, serous retinal detachment is a rare complication ${ }^{(4,5)}$. Although fundus alterations are present in up to $90 \%$ of ALL patients over the course of the disease ${ }^{(5)}$ and up to $50 \%$ at the time of diagnosis $s^{(6)}$, these are usually asymptomatic and are rarely presenting sign of the disease $e^{(5)}$.

The purpose of our study was to describe a case of ALL presenting with bilateral serous macular detachment in an adult.

\section{CASE REPORT}

We describe the case of a 63-year-old female who was admitted to the emergency unit with bilateral, painless, and progressive loss of visual acuity developing over two weeks. The complete clinical history was recorded, and physical examination revealed fever $\left(38.3^{\circ} \mathrm{C}\right)$ and cervical lymphadenopathy.

Best-corrected visual acuity (BCVA) was $2 / 10$ in the right eye and $3 / 10$ in the left eye. Fundus examination (Figure 1 A, B) showed bilateral macular serous detachment, which was confirmed by optical coherence tomography (Figure 1 C, D). Central macular thickness on the right and left eye was $638 \mu \mathrm{m}$ and $423 \mu \mathrm{m}$, respectively. Fluorescein angiography (Figure $1 \mathrm{E}, \mathrm{F}$ ) revealed hyperfluorescent pinpoints in the posterior poles. The limits of the macular detachment were revealed in the late phase of the angiogram.

Blood tests (Table 1) were performed and revealed anemia, neutropenia with $80 \%$ blast cells in the white cell series, thrombocytopenia, and marginally increased C-reactive protein (CRP) levels. Based on these findings, the patient was referred to the Hematology Department, where bone marrow examination was performed (Figure 2), revealing increased cellularity with $97 \%$ blast cells. The patient was diagnosed with ALL type B (CD10+) using immunophenotyping.

Intensive systemic chemotherapy (rituximab-hyperCVAD (fractionated cyclophosphamide, vincristine, doxorubicin, and dexamethasone) regimen plus intrathecal therapy (methotrexate/cytarabine) was
Submitted for publication: September 19, 2014

Accepted for publication: February 3, 2015

Central Lisbon Hospital Center, Lisbon, Portugal.

${ }^{2}$ NOVA Medical School, Lisbon, Portugal.
Funding: No specific financial support was available for this study.

Disclosure of potential conflicts of interest: None of the authors have any potential conflict of interest to disclose.

Corresponding author: Luísa Vieira. José António Serrano St. 1150-199 Lisbon, Portugal E-mail: luisa5vieira@gmail.com 
scheduled and initiated immediately. After the first chemotherapy cycle, complete remission was achieved, and a BCVA of 10/10 was obtained in both eyes with reattachment of the macula (Figure 3) after the second cycle. One year after the diagnosis, the patient remains in complete remission without any ophthalmologic alterations.
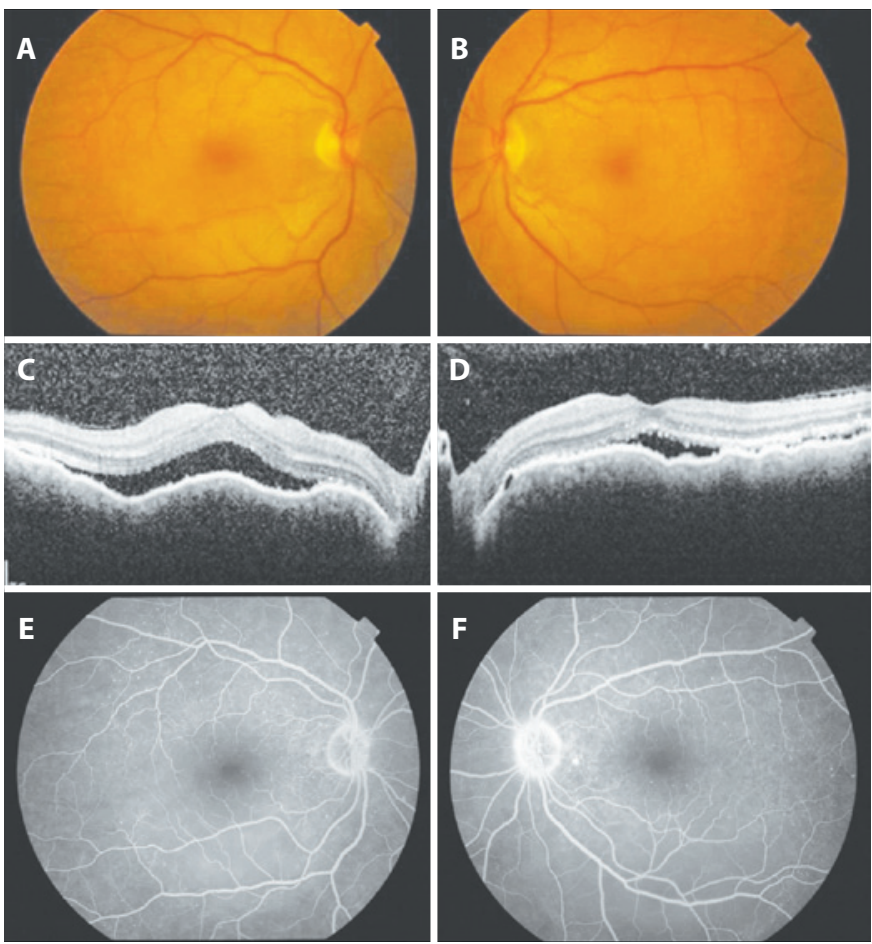

Figure 1. Findings at presentation: A) and B) Fundus photographs of the right and left eye, respectively, showing shallow serous macular detachment. C) and D) Optical coherence tomography (horizontal sections) of the right and left eye, respectively, at the level of the fovea, showing neurosensory detachment, with central macular thickness of $638 \mu \mathrm{m}$ and $423 \mu \mathrm{m}$ in the right and left eye, respectively. E) and F) Fluorescein angiogram of the right and left eye, respectively, showing hyperfluorescent pinpoints in the posterior poles. The limits of the macular detachment were revealed in the late phase of the angiogram.

Table 1. Blood tests performed upon admission

\begin{tabular}{lc}
\hline Erythrocytes $\downarrow$ & $2.42 \times 10^{12} / \mathrm{L}$ \\
Hemoglobin $\downarrow$ & $8.2 \times 10 \mathrm{~g} / \mathrm{L}$ \\
Hematocrit $\downarrow$ & $24.7 \%$ \\
Mean cell volume $\uparrow$ & $102.1 \mathrm{fL}$ \\
Mean cell hemoglobin $\uparrow$ & $33.9 \mathrm{pg}$ \\
Red cell distribution width $\uparrow$ & $17.5 \%$ \\
Leucocytes $\uparrow \uparrow$ & $25.40 \times 10^{9} / \mathrm{L}$ \\
Neutrophils $\downarrow$ & $0.76 \times 10^{9} / \mathrm{L}$ \\
Eosinophils & $0.00 \times 10^{9} / \mathrm{L}$ \\
Basophils & $0.00 \times 10^{9} / \mathrm{L}$ \\
Lymphocytes & $4.32 \times 10^{9} / \mathrm{L}$ \\
Monocytes $\downarrow$ & $0.00 \times 10^{9} / \mathrm{L}$ \\
Blasts $\uparrow \uparrow$ & $80 \%$ \\
Platelets $\downarrow$ & $66 \times 10^{9} / \mathrm{L}$ \\
Platelet distribution width $\uparrow$ & $18.8 \%$ \\
Erythrocyte sedimentation rate & $12 \mathrm{~mm} / \mathrm{h}$ \\
C-reactive protein $\uparrow$ & $14.4 \mathrm{mg} / \mathrm{L}$ \\
Liverand kidneyfunction tests, autoimmune & No alterations \\
test, infection serological tests & \\
\hline
\end{tabular}

\section{DISCUSSION}

Ophthalmological involvement in leukemia, which is more common in acute than in chronic disease ${ }^{(4,6)}$, is not unusual but is rarely a presenting sign of the disease ${ }^{(5)}$. Although leukemic retinopathy (intraretinal hemorrhages, white-centered hemorrhages and cotton-wool spots) is the most frequent fundus finding and retinal infiltrates are easily seen, choroidal infiltration is rarely observed clinically (5). However, the choroid is affected in 30\% to 93\% of the cases as demonstrated by histopathological studies ${ }^{(2,4,7)}$, and decreased thickness after chemotherapy has been reported by Bajenova et al..$^{(7)}$.

When the choroidal infiltration is severe, it leads to serous retinal detachment, which is reported to be shallow in the posterior pole, more common in adults, and bilateral(5).

Other diseases may present with serous macular detachment, such as central serous chorioretinopathy, age-related macular degeneration, Harada's syndrome, melanoma, hemangioma, metastases, sympathetic ophthalmitis, posterior scleritis, and uveal effusion syndrome. In our case, the existence of fever and cervical lymphadenopathy, and the absence of other relevant ophthalmologic or systemic findings, as revealed by clinical history and physical examination, led to the suspicion of hematologic neoplasia, with the angiogram results correlating with the findings described in the scientific lite-

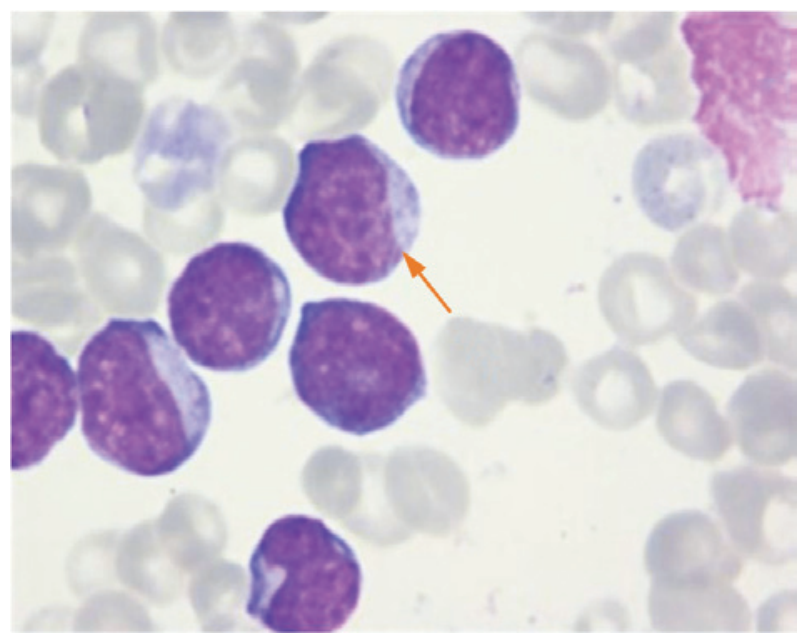

Figure 2. Giemsa-stained smear of bone marrow aspirate. A lymphoblast is indicated by the arrow.
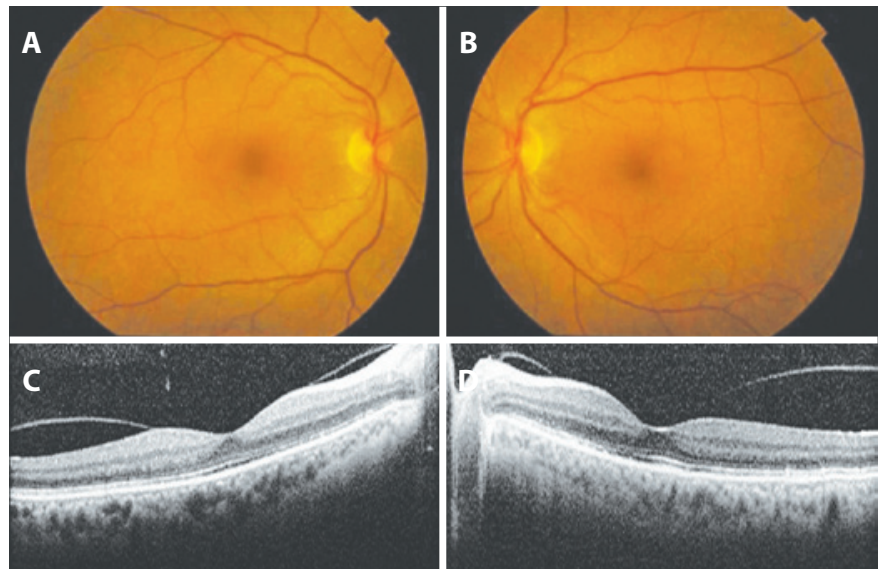

Figure 3. Findings after the second cycle of chemotherapy: A) and B) Fundus photographs of the right and left eye, respectively, with no significant alterations. C) and D) Optical coherence tomography (horizontal sections) of the right and left eye, respectively, at the level of the fovea, showing reattached maculas. 
rature $^{(5)}$. Moreover, the resolution of the macular detachment with systemic chemotherapy was in favor of our theory that serous macular detachment was due to leukemic choroidal infiltration.

The physiopathological mechanism postulated ${ }^{(5)}$ is that choroidal infiltration leads to a decreased blood flow in the choriocapillaris, resulting in ischemia and the disruption of the intercellular tight junctions or the necrosis of the retinal pigment epithelium, as evidenced by the multifocal hyperfluorescent pinpoints in the early phases of fluorescein angiography. This decompensated posterior blood-retinal barrier leads to exudation as evidenced by the diffuse subretinal accumulation of fluorescein in the late phase of the angiogram.

This rare case illustrates the importance of a systematic examination in managing a case of bilateral macular serous detachment, with no other signs suggestive of local injury. This is particularly important when early treatment is imperative and is critical to patient survival.

\section{ACKNOWLEDGEMENTS}

We would like to thank the Department of Hematology for precious contribution in the follow-up of this patient, and the Department of
Orthotics for valuable assistance in the acquisition of images for this article.

\section{REFERENCES}

1. Seiter K. Acute lymphoblastic leukemia. Available at http://emedicine.medscape.com/ article/207631-overview

2. Berthou C, Roncin S, Colin J, Abgrall JF. Ocular sites of acute leukemias. J Fr Ophtalmol. 1996;19(6-7):470-8.

3. Kim DY, Moon JH, Joo YD. Current status and future directions of clinical research and practice in adult acute lymphoblastic leukemia patients in Korea. Blood Res. 2014 Jun; 49(2):80-2.

4. Gordon KB, Rugo HS, Duncan JL, Irvine AR, Howes EL, Jr, O'Brien JM, Carter SR. Ocular manifestations of leukemia: leukemic infiltration versus infectious process. Ophthalmology. 2001;108(12):2293-300.

5. Riss JM, Kaplanski G, Righini-Chossegros M, Harle JR, Escoffier P, Saracco JB. Bilateral serous detachment of neuroepithelium of the posterior pole disclosing acute leukemia. J Fr Ophtalmol. 1990;13(11-12):563-8.

6. Reddy SC, Jackson N. Retinopathy in acute leukaemia at initial diagnosis: correlation of fundus lesions and haematological parameters. Acta Ophthalmol Scand. 2004 Feb; 82(1):81-5.

7. Bajenova NV, Vanderbeek BL, Johnson MW. Change in choroidal thickness after chemotherapy in leukemic choroidopathy. Retina. 2012 Jan;32(1):203-5.

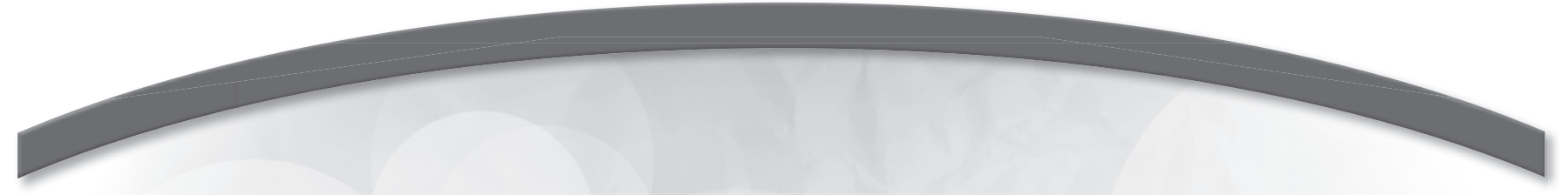

I Curso de Verão em Ciências da Audição, Visão, Comunicação e Estruturas Craniofaciais e Cervicais Departamento de Oftalmologia, Otorrinolaringologia e Cirurgia de Cabeça e Pescoço da Faculdade de Medicina de Ribeirão Preto - USP

\author{
1 a 4 de fevereiro de 2016 \\ Campus da FMRP-USP
}

\title{
Informações:
}

Tel.: (16) 3602-2862

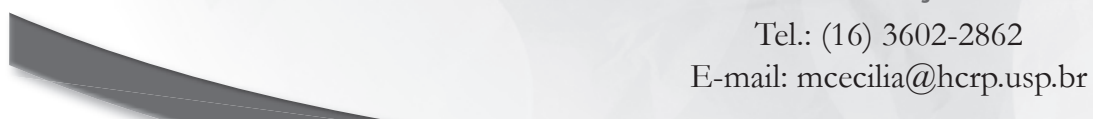

